mgr inż. Jarostaw Czerwiński.

mgr inż. Jan Świątczak

Instytut Pojazdów Szynowych ,TABOR”

\title{
Ogniotrwałe drzwi rozsuwane na ścianie czołowej wagonów osobowych
}

\begin{abstract}
W artykule przedstawiono przebieg procesu projektowania ogniotrwatych drzwi wagonu osobowego. Opisano wykonane badania i uzyskane wyniki. Artykut powstat w wyniku realizacji projektu celowego $n r$ ROW-11-453/2008 „Ogniotrwate drzwi rozsuwane na ścianie czołowej wagonów pasażerskich".
\end{abstract}

\section{Wprowadzenie}

Konstrukcja końca wagonu osobowego powinna powstrzymywać rozprzestrzenianie się ognia, dymu i promieniowania ciepła tak, aby nie nastapił pożar kolejnego pojazdu. Odporność ogniową bada się działając termicznie na ścianę zgodnie ze standardową krzywą temperatury i czasu przedstawioną na rys.1.

Dla wymiernego określenia odporności ogniowej ocenia się zdolność do powstrzy-mywania ognia (szczelność) oraz przenoszenia ciepła (izolacyjność). Kryteriami stanu granicznego szczelności ogniowej są:

- płomień trwający dłużej niż 10 sekund na powierzchni nie nagrzewanej

- powstanie szczeliny o grubości 25 lub $6 \mathrm{~mm} \mathrm{i}$ $150 \mathrm{~mm}$ długości

- zapalenie próbnika $\mathrm{z}$ waty

- uszkodzenie zamka lub zawiasów.

Kryteriami stanu granicznego izolacyjności są przyrosty temperatury na nie nagrzewanej powierzchni drzwi:

- średnia $140^{\circ} \mathrm{C}$

- maksymalna $180^{\circ} \mathrm{C}$.

Wymagania takie zawarte w karcie UIC 564-2 [2] muszą spełniać również drzwi zabudowane w ścianach czołowych wagonów. Pozostałe wymagania konstrukcyjne drzwi zawiera karta UIC 560 [1], a wytrzymałościowe karta UIC 566 [3].

$\mathrm{Z}$ wymienionymi kartami jest zgodna obowiązująca norma PN-K-88208 [5].

Celem realizowanego projektu było opracowanie dokumentacji, wykonania modelu drzwi oraz wykonanie badań. Założono uzyskanie co najmniej 10 minutowej odporności ogniowej.

\section{Realizacja projektu}

$\mathrm{Na}$ wstępie projektu dokonano przeglądu dostępnych i powszechnie stosowanych materiałów charakteryzujących się odpornością na działanie wysokich temperatur. W wyniku weryfikacji dla warunków występujących w wagonach, wytypowano do izolacji drzwi wełnę mineralną, płyty „chłodzące” i uszczelki

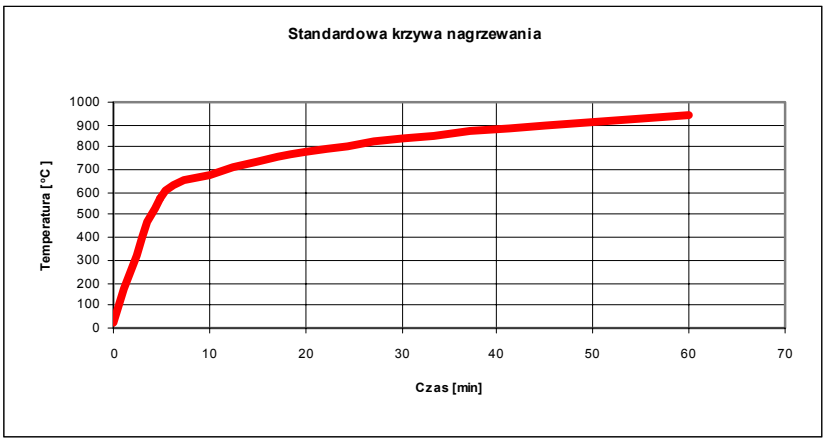

Rys. 1. Standardowa krzywa nagrzewania

pęczniejące. Duży gradient temperatur wymagał opracowania konstrukcji drzwi bez mostków cieplnych i z minimalnymi odkształceniami termicznymi.

Opracowano wstępny model drzwi oparty na stalowym szkielecie z profili cienkościennych wypełnionym wełną mineralną oraz przyklejonym poszyciem $z$ blachy stalowej i płyt Polstop „PAX”. W płytach tych pod wpływem wysokiej temperatury zachodzi reakcja chemiczna w wyniku której następuje schłodzenie powierzchni poszycia. Wykonane analizy wytrzymałości drzwi na obciazżenie próbne [7] oraz odporność termiczną [8] potwierdziły prawidłowość przyjętej konstrukcji skrzydła drzwi. Z uwagi na złożoność zachodzących procesów podczas oddziaływania termicznego, niepełne dane techniczne zastosowanych materiałów, badania modelowe zostały uproszczone, a konstrukcję zweryfikowano poddając próbie rzeczywistą próbkę wycinka drzwi. Próbki drzwi do badań zostały wykonane przez Fabrykę Urządzeń Technicznych ALCON w Żmigrodzie. Materiały izolacyjne zostały dostarczone przez firmy Branddex oraz Rockwoll.

Badania wykonano w firmie Branddex w Stargardzie Szczecińskim. Zabudowę próbki w piecu przedstawiono na rys. 2

Czas trwania próby wyniósł 35 minut. Zmierzono przyrosty temperatury $\mathrm{w}$ piecu i na powierzchni nie ogrzewanej strony próbki. Wyniki próby przedstawiono na rys.3. Szczelność i izolacyjność termiczna została zachowana. 


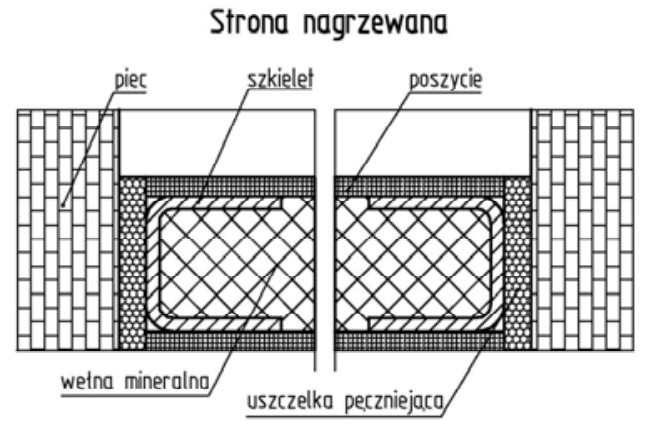

Rys. 2. Przekrój przez próbkę nr 1

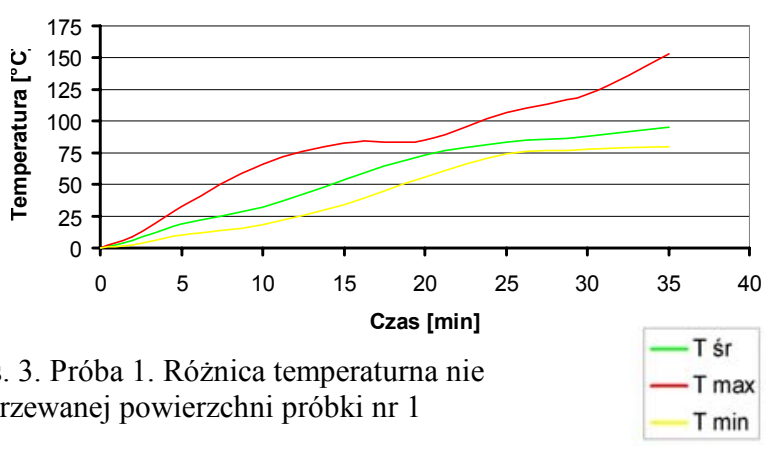

Celem drugiej próby było zweryfikowanie poprawności dwóch koncepcji konstrukcyjnych. Pierwsza dotyczyła sposobu osadzenia, zamknięcia oraz uszczelnienia szyby ognioodpornej. Druga dotyczyła uszczelnienia miejsca styku obu płatów.

Do przeprowadzenia drugiej próby skonstruowano próbkę składającą się z jednego kompletnego skrzydła drzwi oraz wycinka konstrukcji skrzydła drugiego (rys.4).

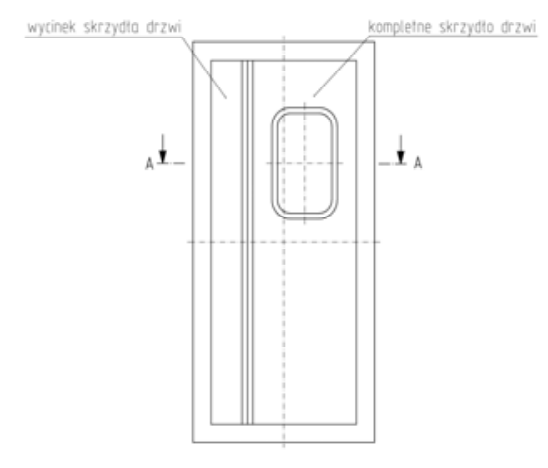

A-A

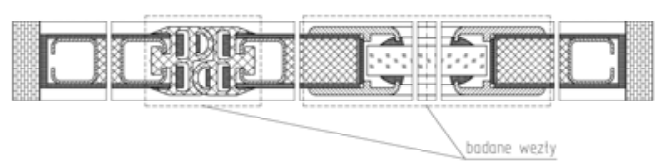

Rys. 4. Próbka nr 2

Próbka nr 2 zachowała odporność ogniową przez 35 minut Stan próbki po badaniach pokazano na rys.5.

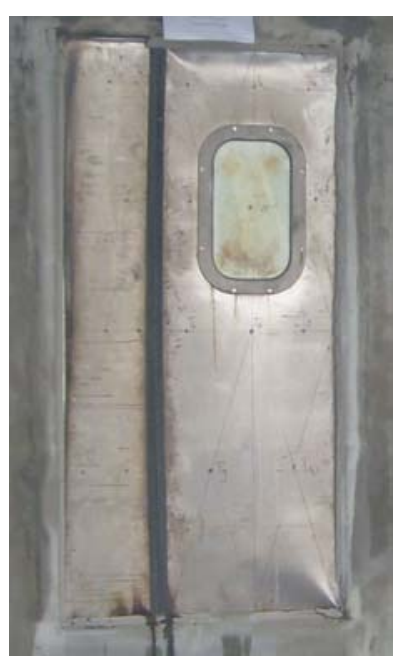

Strona nie nagrzewana

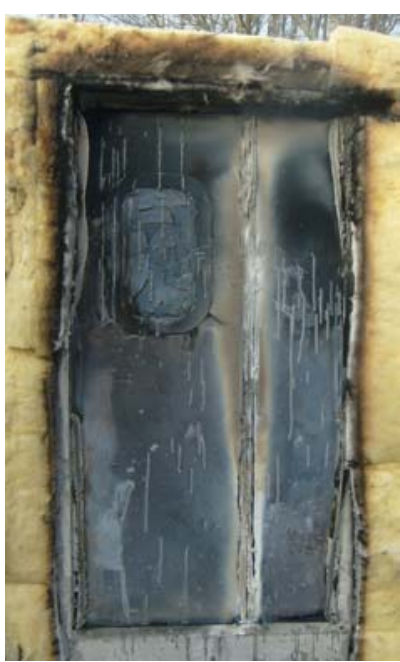

Strona nagrzewana
Rys. 5. Próbka nr 2 po badaniach

Wyniki przeprowadzonych badań dały podstawę do zaprojektowania kompletnych skrzydeł drzwi typu 100ZW przygotowanych do zabudowy w ścianie czołowej wagonu pasażerskiego osobowego typu Z1.

Zaprojektowane drzwi rozsuwane typu 100ZW składają się z dwóch skrzydeł drzwiowych (rys.6) których konstrukcja jest niemal identyczna. Jedno ze skrzydeł wyposażono w gniazdo blokady, a drugie w zamek drzwiowy typu 101ZW.

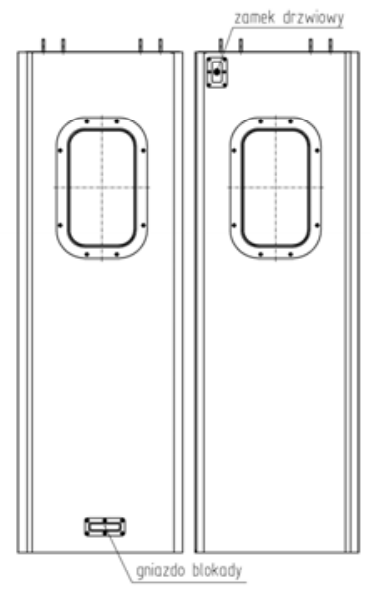

Rys. 6. Ognioodporne drzwi rozsuwane typu $100 \mathrm{ZW}$

Konstrukcję drzwi stanowią: stalowy szkielet, izolacja, poszycia, ognioodporna szyba, uszczelki boczne i prowadnik drzwi.

Stalowy szkielet składa się z: ramy, wzmocnienia i obejmy okna. Rama szkieletu została wykonana w dwóch profili bocznych, górnego oraz dolnego. Profile boczne zostały zaprojektowane tak, aby umożliwić montaż uszczelek bocznych w tych profilach. Profil górny wyposażono $\mathrm{w}$ pręty gwintowane, na których skrzydła podwieszane są do mechanizmu otwierania i zamykania drzwi. Profil dolny przystosowano do montażu prowadnika drzwi. 
Ramę szkieletu wzmocniono dodatkowymi profilami, które oprócz głównej funkcji jaką jest zapewnienie nośności całej konstrukcji drzwi, stanowią dodatkowo oparcie dla izolacji i obejmy okna.

Izolacja drzwi została wykonana z wełny minimalnej i poszyć. Wełna mineralna osadzona jest w szkielecie drzwi i zamykana od zewnątrz poszyciami. Poszycia zbudowane są z blachy stalowej i płyty Palstop „PAX”.

Drzwi wyposażono także w ognioodporną szybę „Promaglass 30”. Osadzona jest ona w obejmie okna i zamknięta od zewnątrz specjalnymi profilami. Do bocznych profili zamontowano uszczelki wykonane $\mathrm{z}$ silikonu uniepalnionego, a w dolnym profilu zabudowano prowadnik drzwi wykonany z tworzywa sztucznego.

Drzwi zostały wyposażone także w szereg uszczelek pęczniejących. Celem ich jest wypełnienie wszelkich szczelin powstałych w konstrukcji samych drzwi jak i między drzwiami a ścianą czołową, przez które możliwe jest przedostanie się ognia. Szczeliny takie istnieją przede wszystkim w węzłach takich jak: styk obu skrzydeł drzwiowych, boczne górne i dolne krawędzie skrzydeł drzwiowych oraz miejsce osadzenia szyby i zamka drzwiowego.

Przekrój poziomy przez skrzydło drzwi przedstawiono na rys.7, natomiast przekrój pionowy na rys.8.

$\mathrm{Na}$ podstawie przygotowanej dokumentacji wykonano model drzwi w rzeczywistej skali. Drzwi zabudowano w przygotowanym do prób wycinku ściany czołowej wagonu typu Z1. Drzwi do prób nie zostały wyposażone w mechanizm zamykający.

Badanie odporności ogniowej drzwi odbyło się w Centrum Techniki Okrętowej w Gdańsku. Metodyka i warunki badania były zgodne z normą PN-EN 1363-1 [3] oraz PN-EN 1634-1 [5].

Podczas próby w 10 minucie nastapiło rozsunięcie skrzydeł drzwi i utrata szczelności ogniowej pomiędzy płatami drzwi. Izolacyjność termiczna drzwi została zachowana.

Do kolejnej próby drzwi wyposażono w układ symulacyjny docisk skrzydeł drzwi przez mechanizm otwierania i zamykania. Zabudowane drzwi do próby pokazano na rys.9. Na rys.10 przedstawiono przyrost temperatury na nie nagrzewanej powierzchni drzwi. Izolacyjność termiczna drzwi została zachowana. Szczelność ogniowa została utracona w 14 minucie

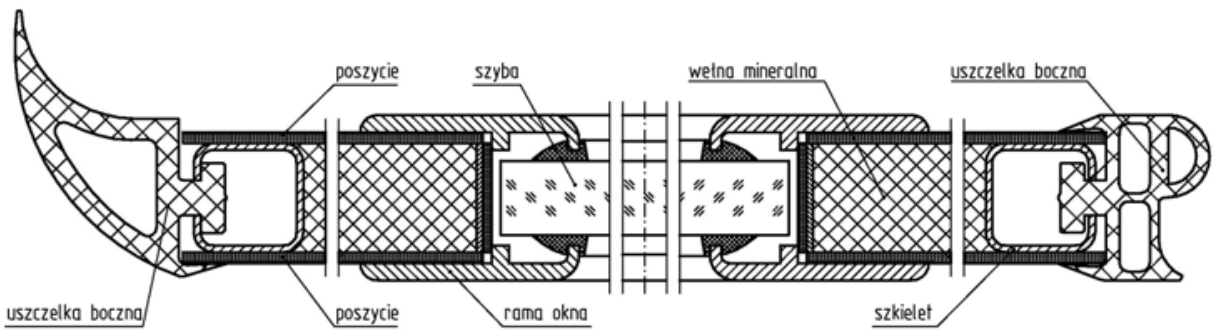

Rys. 7. Przekrój poziomy przez skrzydło drzwi próby. Zostało przekroczone kryterium płomienia trwającego dłużej niż 10s. Utrata szczelności spowodowana była przepaleniem uszczelki z silikonu na styku skrzydeł drzwi.

$\mathrm{Na}$ rys.11 pokazano nagrzewaną stronę drzwi bezpośrednio po odsunięciu od pieca.

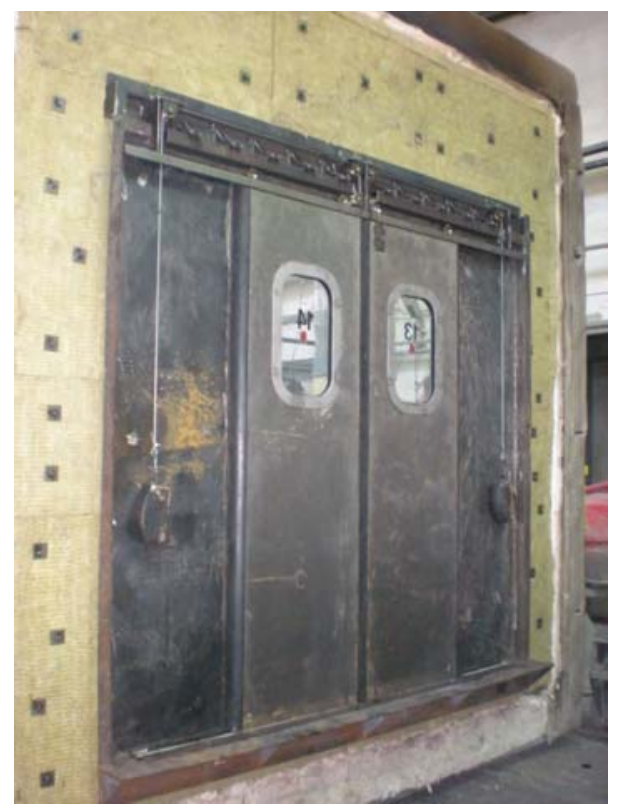

Rys. 9. Drzwi zabudowane w piecu przed próbą

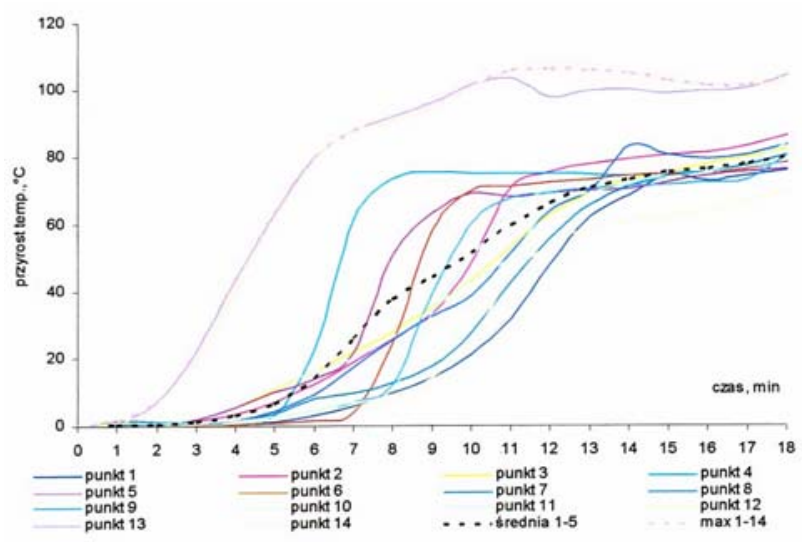

Rys. 10. Przyrost temperatury na nie nagrzewanej powierzchni drzwi 100ZW

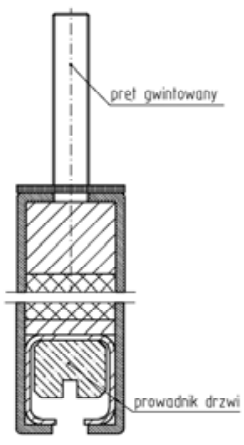

Rys. 8. Przekrój poziomy przez skrzydło drzwi 


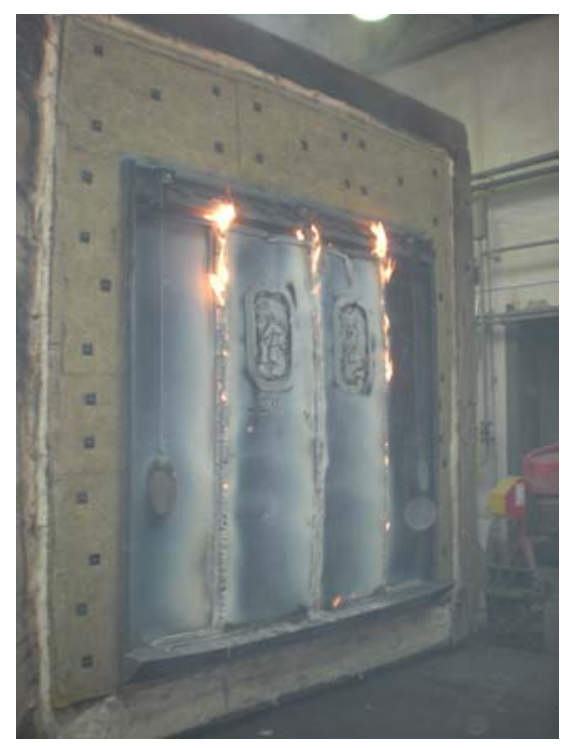

Rys. 10. Drzwi 100ZW po próbie

\section{Podsumowanie}

Zaprezentowane drzwi typu 100ZW zapewniaja kilkunastominutowe powstrzymanie ognia płonącego wewnątrz wagonu osobowego. IPS „Tabor” prowadzi dalsze prace konstrukcyjne, którym celem jest uzyskanie dłuższego czasu odporności ogniowej drzwi.

Efekt wprowadzonych zmian konstrukcyjnych geometria i materiał uszczelnienia, zostanie sprawdzony w kolejnych badaniach.

\section{Literatura}

[1] Karta UIC 560 Drzwi, pomosty wejściowe, okna, stopnie, uchwyty i poręcze wagonów osobowych $i$ wagonów bagażowych.

[2] Karta UIC 564-2 Przepisy o zapobieganiu przeciw pożarowym $i$ zwalczaniu ognia $w$ pojazdach szynowych do komunikacji międzynarodowej, w których przewozi sie pasażerów lub przyłqczanych wagonach typu pasażerskiego.

[3] Karta UIC 566 Obciażenia pudet wagonów pasażerskich i ich części dobudowanych.

[4] PN-EN 1363-1 Badania odporności ogniowej. Część 1: Wymagania ogólne.

[5] PN-EN 1634 Badania odporności ogniowej $i$ dymoszczelności zespołów drzwiowych żaluzjowych $i$ otwieranych okien oraz elementów budowlanych cześć 1. Badania odporności ogniowej drzwi, żaluzji i otwieranych drzwi.

[6] PN-K-88208 Wagony osobowe. Drzwi czolowe rozsuwane. Wymagania i metody badań.

[7] OR-9651 Sprawozdanie z analizy wytrzymatości drzwi czołowych rozsuwanych.

[8] OR-9655 Sprawozdanie $z$ analizy termicznej $w$ strukturze drzwi czolowych rozsuwanych. 